Subjective social well-being of employees

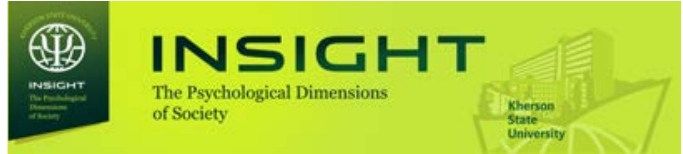

with different socioeconomic statuses

DOI: 10.32999/2663-970X/2021-6-5

Link article (Style APA): Blynova, O. Ye., \& Kruhlov, K. O. (2021). Subjective social well-being of employees with different socioeconomic statuses. Insight: the psychological dimensions of society, 6, 57-71. DOI: 10.32999/2663-970X/2021-6-5

Link article (Style DSTU 8302: 2015): Blynova, O. Ye., Kruhlov, K. O. Subjective social well-being of employees with different socioeconomic statuses. Insight: the psychological dimensions of society, 2021, 6, 57-71. DOI: 10.32999/2663-970X/2021-6-5

UDC 316.6: 159.923.2

\title{
Subjective social well-being of employees with different socioeconomic statuses
}

\section{Суб'єктивне соціальне благополуччя співробітників з різним соціально-економічним статусом}

Received: May 31, 2021

\section{Blynova Olena Yevhenivna}

Doctor of Psychological Sciences, Professor

Department of Psychology

Kherson State University, Ukraine

elena.blynova@gmail.com , https://orcid.org/0000-0003-3011-6082

\section{Kruhlov Kostiantyn Oleksandrovych \\ Postgraduate Student \\ Department of Psychology \\ Kherson State University, Ukraine \\ kruglov@universum.com.ua , \\ https://orcid.org/0000-0002-4919-3275}

Accepted: November 11, 2021

\author{
Блинова Олена Євгенівна \\ доктор психологічних наук, професор \\ кафедра психології \\ Херсонський державний університет, \\ Україна \\ elena.blynova@gmail.com , \\ https://orcid.org/0000-0003-3011-6082 \\ Круглов Костянтин Олександрович \\ аспірант \\ кафедра психології \\ Херсонський державний університет, \\ Україна \\ kruglov@universum.com.ua , \\ https://orcid.org/0000-0002-4919-3275
}

\begin{abstract}
The purpose of the research is to specify differences in the subjective social well-being of an organization's employees with different socioeconomic statuses. The following methods have been used to conduct the empirical research $(n=38)$ : theoretical analysis and generalization of scholarly views of the problem; empirical methods: "Questionnaire of Subjective Social Well-Being” (T.V. Danylchenko); "Questionnaire of Subjective Economic Well-Being" (V.O. Khashchenko); the methods of statistical analysis: correlation analysis; F-test. Results. The authors have established statistically significant correlations between the criteria of subjective social well-being and subjective economic
\end{abstract}

\begin{abstract}
Анотація
Метою дослідження $є$ встановлення відмінностей у суб'єктивному соціальному благополуччі співробітників організації з різним соціально-економічним статусом. Для проведення емпіричного дослідження ( $\mathrm{n}=38$ ) застосовано методи: теоретичного аналізування та узагальнення наукових поглядів до проблеми; емпіричні методи: “Опитувальник параметрів суб’єктивного соціального благополуччя” (Т. В. Данильченко); “Опитувальник суб'єктивного економічного благополуччя" (В.O. Хащенко); методи статистичного аналізування, а саме, кореляційний аналіз, $\varphi$-критерій кутового перетворення Фішера.
\end{abstract}


well-being, namely, between the scales "Social visibility", "Social remoteness" and the indices of economic optimism, economic anxiety, and financial deprivation. It has been confirmed the statistical interdependence between the scales "Emotional acceptance" and "Family well-being index". The research has determined differences between employees' groups, which were divided according to socioeconomic status (managers and "performers"), on the following scales: "Social visibility", "Positive social perceptions", and "Economic optimism index". Conclusions. The employees with higher socioeconomic status recognize their influence, the capability to settle problems, the availability of social ties, financial, economic, material, and social resources due to which they are confident when coping with stressful situations, have a positive economic expectation, a high level of efficient social functioning. The employees with low socioeconomic status are mainly characterized by unsatisfactory emotional and social relations, a failure to actively influence their social environment; they feel economic anxiety about their finances and the future.

Keywords: social status, employees of organization, economic well-being, subjective economic well-being, mental well-being.

\section{Introduction}

The modern trend in production management is the understanding that efficient and rational use of labor potential should become a basis for improving management techniques. In studying the value-motivational realm, skills, knowledge, and occupational skills of employees, psychology of management gives pride of place to such a resource as mental well-being (Kruhlov, Blynova, 2019; Fofanova \& Havrylchyk, 2017; Shamyonov, 2014; Choudhury \& Barman, 2014).

One of the most crucial indices characterizing the interaction between individual-personal and macro-social levels of staff behavior within a company is socioeconomic status which is considered a complex criterion that, as a rule, involves three key parameters (Ovcharova, 2012; Rodina, 2013: 216):

Economic status, which is estimated by wage rates;

Social status, which is estimated by education;

Labor status, which is estimated by a type of profession and occupational level.

Socioeconomic status is an outcome of the interaction between productive-economic and social systems of society. During production
Результати. Встановлено наявність статистично значущих кореляційних взаємов'язків між параметрами суб'єктивного соціального благополуччя та суб’єктивного економічного благополуччя, а саме, між шкалами "Соціальна помітність", “Соціальна дистантність" та індексами економічного оптимізму, економічної тривожності, фінансової депривованості. Констатовано статистичну взаємозалежність між шкалами "Емоційне прийняття" та “Індекс благополуччя сім'ї”. Визначено відмінності між групами співробітників, які розділено за соціально-економічним статусом (менеджери та "виконавці"), за шкалами: “Соціальна помітність”, “Позитивні соціальні судження”, “Індекс економічного оптимізму”. Висновки. Співробітники з більш високим соціально-економічним статусом усвідомлюють свою впливовість, здатність вирішувати проблеми, наявність соціальних зв'язків, фінансових, економічних, матеріальних та соціальних ресурсів, завдяки чого відчувають свою спроможність долати складні стресові ситуації, мають позитивні економічні очікування, високий рівень ефективного соціального функціонування. Співробітники $з$ низьким соціально-економічним статусом мають переважно незадовільні емоційні та соціальні стосунки, неможливість активно впливати на своє соціальне оточення, відчувають економічну тривожність стосовно своїх матеріальних можливостей та свого майбутнього.

Ключові слова: соціальний статус, співробітники організації, економічне благополуччя, суб’єктивне економічне благополуччя, психологічне благополуччя.

\section{Вступ}

Сучасною тенденцією в управлінні виробництвом є розуміння того, що основою вдосконалення прийомів та методів управління має стати ефективне та раціональне використання трудового потенціалу. Психологія управління, вивчаючи ціннісно-мотиваційну сферу, вміння, знання, трудові навички співробітників, достатню увагу приділяє такому ресурсу, як психологічне благополуччя (Круглов, Блинова, 2019; Фофанова, Гаврильчик, 2017; Шамионов, 2014; Choudhury, Barman, 2014).

Одним із важливих показників, який характеризує взаємодію індивідуально-особистісного та макросоціального рівнів організації поведінки співробітників в організації, є соціально-економічний статус, який розглядається як комплексний критерій, та, як правило, містить у собі три ключових параметри (Овчарова, 2012; Родіна, 2013: 216):

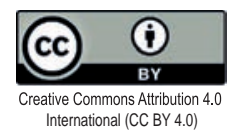


Subjective social well-being of employees with different socioeconomic statuses

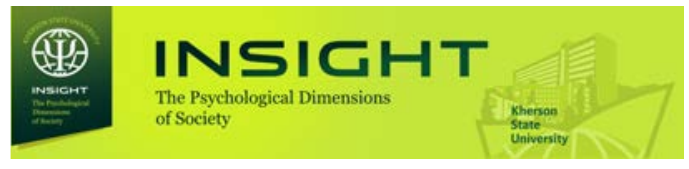

activities, peopleacquire a particular socioeconomic status which is based on the following indices: income level, living conditions, property availability, a degree of satisfaction with needs for various services - consumer, medical, transport, etc. (Rodina, 2013: 217).

A great deal of sociological and psychological research focuses on the interdependence between socioeconomic status and the mental well-being of personality (Muzdybaev, 2001; Chopik, 2017; Rodyna, 2013; Donald G.Gardner, 2020).

However, the level of realization and evaluation of one's social position and socioeconomic status is predominantly determined by the processes of social categorization, social identification, and social comparison. The above actualizes the examination of rather social mental well-being resulted in satisfaction with one's social needs for recognition, prestige, maintenance of self-esteem than mental well-being as a personal state.

The purpose is to specify differences in the subjective social well-being of an organization's staff with different socioeconomic statuses.

\section{Methodology and methods}

The authors rely on analyzing scientific interpretations of interrelations of a person's socioeconomic status and his mental well-being, mental health. Coherence between mental wellbeing and economic differentiation in society is highlighted by socio-psychological research (Korobka, 2012; Kruhlov, Blyskun, 2020; Chopik, 2017; Min Gwan Shin et al., 2020) stating that a low income is an unfavorable factor for personal growth.

The inequality of income, and thus resources and opportunities, causes psychosocial stress, which degrades mental well-being soon or late. There is a higher probability of the emergence of stress factors within groups with low socioeconomic status; at the same time, the representatives of these groups have fewer resources to overcome them (Husev, 2013; Kanibolotska, 2014; Korobka, 2012; Keyes, Westerhof, 2012).

First, a high position in the socioeconomic hierarchy can reduce stress and its effects because high socioeconomic status reduces the likelihood that a person will encounter negative events. Second, the employees who hold lower positions in the social hierarchy have fewer social
1) Економічний статус, який оцінюється за рівнем доходу;

2) Соціальний статус, який оцінюється за рівнем освіти;

3) Трудовий статус, який оцінюється за типом професії та рівнем зайнятості.

Соціально-економічний статус $є$ результатом взаємодії виробничо-економічної і соціальної системи суспільства. У процесі виробничої діяльності люди набувають певного соціально-економічного статусу, який визначається такими показниками: рівнем доходів, житловими умовами, майновою забезпеченістю, ступенем задоволення потреб у різноманітних послугах - побутових, медичних, транспортних тощо (Родіна, 2013: 217).

Взаємозалежність між соціально-економічним статусом та рівнем психологічного благополуччя особистості простежується у багатьох соціологічних та психологічних дослідженнях (Муздыбаев, 2001; Chopik, 2017; Родына, 2013; Donald G.Gardner, 2020).

Проте, рівень усвідомлення та оцінювання своєї соціальної позиції, свого соціально-економічного статусу значною мірою визначається процесами соціальної категоризації, соціальної ідентифікації, соціального порівняння, що робить актуальним розгляд не стільки психологічного благополуччя як особистісного стану, скільки соціального психологічного благополуччя як результату задоволення своїх соціальних потреб у визнанні, престижності, підтриманні самооцінки.

Мета: встановлення відмінностей у рівні суб'єктивного соціального благополуччя співробітників з різним соціально-економічним статусом.

\section{Методологія та методи}

Звернемось до аналізування наукових пояснень взаємозв'язку соціально-економічного статусу людини та ії психологічного благополуччя, психологічного здоров'я. Зв'язок психологічного благополуччя 3 економічною диференціацією у соціумі підкреслено в соціально-психологічних дослідженнях (Коробка, 2012; Круглов, Блискун, 2020; Chopik, 2017; Min Gwan Shin et. al., 2020), у яких відзначається, що малозабезпеченість $є$ несприятливим чинником стосовно особистісного благополуччя.

Нерівність доходів і, відповідно, ресурсів та можливостей, сприяє виникненню психосоціального стресу, який із часом знижує

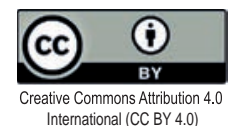


and economic resources to cope with stressful situations (Arshava, Nosenko, 2012; La Placa et. al., 2013). According to K. Muzdybaiev, poverty causes low spirit, tension, depression that, in turn, leads to ineffective behaviors. Most poor people often suffer frustration and believe that no one cares about them (Muzdybaiev, 2001). The research by L. Korobka emphasizes the poor have a low level of satisfaction with many aspects of their life: they mainly feel unhappy, tired, their mood is depressed, and the indicator of subjective well-being is lower compared to the well-heeled (Korobka, 2012).

Modern science studies well-being from two perspectives: on the one hand, it refers to social well-being, well-being within a community (Danylchenko, 2017) and, on the other hand, subjective feelings related to social relations are under examination (Arshava \& Nosenko, 2012; Shamyonov, 2014). It is worth mentioning sociology comprises a great deal of research on social well-being. Although, T. V. Danylchenko believes the optimal state of a person in the social interaction of different levels, which the author defines as subjective social well-being, is poorly studied. The author attributes the following elements to the relevant concept: satisfaction with own social status, prospects and the current state of society one belongs to, interpersonal relationships, personal status, and meeting of social needs (Danylchenko, 2017).

The findings of empirical research that have justified that the level of human wellbeing in society doesn't often coincide with one's subjective well-being spark the interest. That sort of difference in the eudemonistical approach to well-being is explained by the fact that its level is concurrently generated by internal factors (autonomy) and external factors (social coherence). Nevertheless, theoretical provisions consider the influence of the above factors consistent, but empirical research doesn't support this idea (Fofanova \& Havrylchyk, 2017; Diener, 2013; Min Gwan Shin et al., 2020).

The main criterion for evaluating the quality and level of well-being is social interaction which embraces the processes of social comparison, correlation of personal well-being with others. Therefore, the concept "social well-being" is показники психологічного благополуччя. У групах із низьким соціально-економічним статусом більш високою $є$ ймовірність виникнення стресових факторів, водночас представники таких груп мають менше ресурсів, щоб їх подолати (Гусев, 2013; Каніболоцька, 2014; Коробка, 2012; Keyes, Westerhof, 2012).

По-перше, висока позиція у соціальноекономічній ієрархії може знизити стрес і його наслідки, оскільки більш високий соціальноекономічний статус знижує ймовірність того, що особистість зіткнеться 3 негативними подіями. По-друге, співробітники, які займають нижчі позиції у соціальній ієрархії, мають менше соціальних та економічних ресурсів для подолання стресових подій (Аршава, Носенко, 2012; La Placa et. al., 2013). Як зазначає К. Муздибаєв, бідність зумовлює стан пригніченості, напруженості, депресії, що, у свою чергу, призводить до неефективних форм поведінки. Більшість бідних перебуває у стані постійної фрустрації та вважає себе нікому непотрібними (Муздыбаев, 2001). У дослідженні Л. Коробки підкреслено, що для бідних характерноює низька задоволеність багатьма аспектами свого життя, вони переважно відчувають себе нещасними, стомленими, їхній настрій є пригніченим, а індикатор суб'єктивного благополуччя нижче, порівняно із більш забезпеченими особами (Коробка, 2012).

У сучасній науці проблема благополуччя вивчається в двох напрямах, з одного боку, мова йде про соціальне благополуччя, благополуччя у спільноті (Данильченко, 2017), 3 іншого боку, досліджуються суб'єктивні переживання, пов'язані із соціальними відносинами (Аршава, Носенко, 2012; Шамионов, 2014). Слід відмітити значну кількість досліджень соціального самопочуття у соціології, проте у психології, на думку Т.В. Данильченко, недостатньо приділяється увага вивченню оптимального стану людини при соціальних взаємодіях різного рівня, який визначено автором як суб'єктивне соціальне благополуччя. До змісту цього поняття автор включає: задоволеність своїм соціальним статусом, перспективами та актуальним станом суспільства, до якого належить, міжособистісними зв'язками, особистісним статусом, задоволенням соціальних потреб (Данильченко, 2017).

Цікавими $є$ результати емпіричних досліджень, які засвідчили, що рівень благополуччя людини в соціумі далеко не завжди збігається

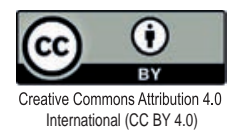


Subjective social well-being of employees with different socioeconomic statuses

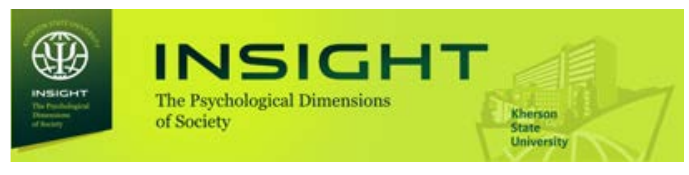

3 їі суб'єктивним психологічним благополуччям. Таке розходження в евдемоністичному підході до благополуччя пояснюється тим, що його рівень водночас зумовлюють внутрішні чинники (автономія) та зовнішні чинники (соціальна зв'язність). Хоча в теоретичних положеннях вплив цих груп чинників вважається узгодженим, в емпіричних дослідженнях це не підтверджується (Фофанова, Гаврильчик, 2017; Diener, 2013; Min Gwan Shin et. al., 2020).

Головним критерієм оцінювання якості та рівня благополуччя $€$ соціальна взаємодія, в якій відбуваються процеси соціального порівняння, співвіднесення благополуччя свого та інших людей. Отже, поняття "соціальне благополуччя" застосовують для вивчення ступеня та рівня задоволеності людей своїми соціальними контактами, становищем, забезпеченістю, перспективами у суспільстві (Данильченко, 2017; Круглов, Блинова, 2019; Хащенко, 2011; Шамионов, 2014).

P.М. Шаміонов розглядає соціальне благополуччя як задоволеність особистості своїм соціальним статусом, задоволеність міжособистісними зв'язками та статусом в мікросоціальному оточенні (Шамионов, 2014). Т.В. Данильченко соціальне благополуччя розглядає через задоволеність соціальним статусом, міжособистісними стосунками, підкреслюючи суб'єктивну сторону такого переживання. Тому вона пропонує розрізняти соціальне благополуччя та "суб'єктивне соціальне благополуччя" (Данильченко, 2017). S.R. Choudhury, A. Barman також акцентують увагу на соціальному аспекті та розглядають благополуччя через "наявність соціальної підтримки, прийняття групою, відкритість у взаєминах та відсутність конфліктів, сприятливе соціальне оточення і керування навколишнім середовищем, включення в поняття особистого благополуччя благополуччя близьких та значущих людей" (Choudhury \& Barman, 2014: 260).

Також слід відзначити наукову працю Min Gwan Shin iз співавторами, де міжособистісне благополуччя як задоволеність якістю міжособистісних стосунків відрізняється від соціального благополуччя як задоволеності своїм соціальним статусом та соціальними ролями (Min Gwan Shin et. al., 2020).

Отже, у підходах та визначеннях благополуччя підкреслюється соціальний аспект, тобто якість взаємодії із соціальними об'єктами різних рівнів. and activities of a social environment a person 
lives in; social integration: assessment of a social environment a person belongs to as healthy, vital, and safe. To identify the level of social integration, it is used different concepts: "cohesion", confidence", "tolerance", "fidelity", "social capital".

Therefore, when assessing well-being, the authors have regard to the individual's comparison with standards, subjective etalons. Such an assessment has social nature and two sides: on the one hand, comparison with something that exists in society as a certain standard of social life, social success, development opportunities, external indicators of well-being and, on the other hand, social comparison is based on personal achievements, individual criteria, and attainment of the desired state (Diener, 2013).

The authors agree with the research findings of T.V. Danylchenko stating that subjective wellbeing is identified by individual's realization of own resources and opportunities to achieve the desired status in the social system and, at the same time, the acceptance of image, status, prestige of a person and his social roles by others. Thus, when it refers to satisfaction with one's job, socioeconomic status, this conditionality comprises the achievement of personal goals, social approval, and self-esteem improvement. T.V. Danylchenko proved in her research that feedback is of importance - people with a high level of subjective well-being experience greater social coherence and achieve higher levels of activity (Danylchenko, 2017).

Participants. The study engages 38 employees of law and customs enterprises. Among them, 17 employees (group 1) belong to mid- and highranking managers: they have a better education and income level, i.e., a higher socioeconomic status, that is esteemed as an objective indicator. Other 21 employees belong to the group of "performers" (group 2 with lower socioeconomic status). Age and sex distribution in both groups is approximately the same.

Procedure and methods. The following methods have been applied while conducting the empirical research: "Questionnaire of Subjective Social Well-Being" (T.V. Danylchenko) which consists of 36 questions; according to the instruction, a study participant should evaluate his/her social life for the last three months on
В американській психологічній науці відомою $\epsilon$ концепція соціального благополуччя К. Л. М. Кіза. Автор виділяє п'ять критеріїв оптимального функціонування людини в соціумі (Keyes \& Westerhof, 2012), які враховано Т.В. Данильченко при обгрунтуванні, розробці та апробації власного опитувальника: соціальне прийняття - позитивні уявлення про людську природу та відчуття комфорту при взаємодії з іншими людьми; соціальна актуалізація - оптимістична оцінка потенціалу та вектору розвитку суспільства, його майбутнього, тому власне соціальне просування $\epsilon$ позитивним; соціальний внесок - оцінка власної цінності для суспільства, відчуття своєї ефективності та відповідальності; соціальна залученість - позитивна оцінка якості, організації та діяльності соціального середовища, в якому живе людина; соціальна інтеграція - оцінка соціального середовища, в якому людина перебуває, здоровим, життєздатним, безпечним. Для позначення рівня соціальної інтеграції використовують різні поняття: "згуртованість”, “довіра”, “толерантність”, “відданість”, “соціальний капітал”.

Таким чином, при визначенні благополуччя враховуємо результати порівняння особистістю себе із нормами, суб'єктивними еталонами. Таке оцінювання має соціальний характер, містить дві сторони, з одного боку, порівняння з чимось, що існує у суспільстві як певний стандарт соціального життя, соціальної успішності, можливості розвитку, зовнішні показники добробуту. 3 іншого боку, соціальне порівняння спирається на особисті досягнення, на індивідуальні критерії, на отримання бажаного стану (Diener, 2013).

Погоджуємось із висновками дослідження Т.В. Данильченко щодо того, що суб'єктивне благополуччя визначається усвідомленням індивідом власних ресурсів та можливостей для досягнення бажаного положення в соціальній системі та водночас - через сприймання іншими людьми іміджу, статусу, престижу людини, її соціальних ролей. Тому, коли мова йде про задоволеність діяльністю, своїм соціально-економічним статусом, то ця обумовленість містить і досягнення особистих цілей, і соціальне схвалення, і підвищення самооцінки. Як довела у своєму дослідженні Т.В. Данильченко, важливим $є$ наявність зворотного зв'язку - люди 3 високим рівнем суб'єктивного благополуччя відчувають

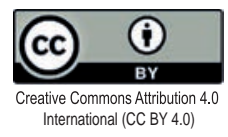


Subjective social well-being of employees with different socioeconomic statuses



більшу соціальну залученість і досягають більш високих рівнів активності у діяльності (Данильченко, 2017).

Учасники. У дослідженні взяли участь 38 співпрацівників підприємства, основним видом діяльності якого є юридична та податкова. Серед них 17 працівників (група 1) належать до групи менеджерів середньої та високої ланок, вони мають більш високий рівень освіти та рівень доходів, тобто більш високий соціально-економічний статус, вважаємо це об'єктивним показником. Ще 21 співробітник належать до групи “виконавців" (група 23 більш низьким соціально-економічним статусом). Віковий та статевий розподіл в обох групах є приблизно однаковим.

Процедура і методи. Для проведення емпіричного дослідження застосовано такі методи.

“Опитувальник параметрів суб’єктивного соціального благополуччя” (Т.В. Данильченко), який містить 36 питань, за інструкцією досліджуваний має оцінити своє соціальне життя за останні три місяці за шкалою: 1 - абсолютно не згоден; 2 - не згоден; 3 - швидше не згоден; 4 - щось посередині; 5 - швидше згоден; 6 згоден, 7 - абсолютно згоден. Опитувальник дозволяє визначити суб'єктивне соціальне благополуччя за параметрами: 1. Соціальна помітність; 2. Соціальна дистантність; 3. Емоційне прийняття; 4. Соціальне схвалення; 5. Позитивні соціальні судження. Обробка первинних результатів відбувається за допомогою ключа до методики (Данильченко, 2015).

Для оцінювання суб'єктивного параметра соціально-економічного статусу нами застосовано “Опитувальник суб’єктивного економічного благополуччя” (В.О. Хащенко). Суб'єктивне економічне благополуччя описується науковцем через співставлення фактичного статусу людини з їі рівнем домагань, потребами та сприйняттям власного становища, або з тим, якою є фінансове становище референтних осіб (типових, подібних або авторитетних). Суб'єктивне економічне благополуччя $\epsilon, 3$ одного боку, складовою частиною, компонентом загального суб'єктивного благополуччя (або задоволеності життям), з іншого боку - самостійним чинником його детермінації, джерелом загального благополуччя людини, значення якого то зростає, то знижується у різні періоди життя (Хащенко, 2011).

Опитувальник розроблений для оцінювання рівня суб'єктивного економічного the degree of wealth (funds) (25 points); EOI - 
economic optimism index renders the optimistic or pessimistic assessment of external and internal conditions of growth of material well-being (30 points); EAI - economic anxiety index renders the degree of financial stress (35 points) - in this scale, the higher indicator, the lower level of economic anxiety.

Statistical analysis. The data were processed using statistical software "SPSS" (version 23.0) and "MS Excel". The authors have applied Spearman's $\rho$ to determine correlation coefficients and F-test to substantiate the differences between the groups statistically.

\section{Results and discussion}

The authors present the results obtained according to the Questionnaire of Subjective Social Well-Being (T. V. Danylchenko). It is worth mentioning that under the author's data, there are significant statistical differences in all the scales (except for "Social visibility") between female and male samples; thus, data have been processed separately for men and women and transformed into sten scores. Sten scores have been added to the general table for the further analysis (see table 1).

Table 1. Mean values and standard deviations on the scales of the Questionnaire of Subjective Social Well-Being (T. V. Danylchenko) $(\mathrm{n}=38)$

Таблиця 1. Середні значення та середньоквадратичні відхилення за шкалами методики “Опитувальник параметрів суб'єктивного соціального благополуччя" (Т.В. Данильченко) $(\mathrm{n}=38)$

\begin{tabular}{|l|c|c|}
\hline \multicolumn{1}{|c|}{$\begin{array}{c}\text { Scale name } \\
\text { Шкала }\end{array}$} & M & SD \\
\hline $\begin{array}{l}\text { Social visibility } \\
\text { Соціальна помітність }\end{array}$ & 5.84 & 1.273 \\
\hline $\begin{array}{l}\text { Social distance } \\
\text { Соціальна дистантність }\end{array}$ & 6.12 & 1.351 \\
\hline $\begin{array}{l}\text { Еmotional ассерtance } \\
\text { Емоційне прийняття }\end{array}$ & 6.76 & 1.437 \\
\hline Social approval & 5.29 & 1.083 \\
\hline $\begin{array}{l}\text { Positive social judgments } \\
\text { Позитивні соціальні судження }\end{array}$ & 5.41 & 1.122 \\
\hline
\end{tabular}

Note: *a scale name in the table is in line with the pole scale with high scores; $\mathrm{M}$ - arithmetic mean; SD - mean square deviation.

Примітка: *назва шкал у таблиці відповідає полюсу шкали з високими балами; M - середнє арифметичне; SD - середнє квадратичне відхилення. благополуччя як психологічного показника у житті людини, який виражає ставлення до матеріальних аспектів життя та життєву позицію людини у сфері матеріального споживання. Опитувальник містить п'ять шкал - економічного оптимізму, поточного добробуту родини, фінансової депривованості, суб'єктивної адекватності доходу, економічної тривожності.

При валідизації опитувальника встановлено, що респондентів, які мають високий бал, порівняно із низьким, відрізняє висока оцінка власного доходу, задоволеність фінансовим становищем, менший акцент на значущості цінності матеріальної забезпеченості, висока самооцінка, інтернальність та впевненість в економічних досягненнях. а також задоволеність життям. Для кожної шкали методики визначено різну кількість балів: ІАД - індекс суб'єктивної адекватності доходу запитам та потребам особистості (20 балів); ІБС - індекс поточного благополуччя сім'ї, що відображає суб'єктивні оцінки матеріального становища сім'ї (20 балів); ІНД - індекс фінансової депривованості, що відображає міру достатку фінансових засобів (коштів) (25 балів); IEO - індекс економічного оптимізму та впевненості, який відображає оптимістичну чи песимістичну оцінку зовнішніх та внутрішніх умов зростання матеріального благополуччя (30 балів); IET - індекс економічної тривожності, відображає міру виразності фінансового стресу (35 балів), у цій шкалі чим вищим є показник, тим меншим $є$ рівень економічної тривожності.

Статистичне аналізування. Дані оброблено статистичними програмами "SPSS" (версія 23.0) та "MS Excel”. Визначення коефіцієнтів кореляції відбувалося через коефіцієнт кореляції Спірмена, для статистичного обгрунтування відмінностей між групами ми скористалися $\varphi$-критерієм кутового перетворення Фішера.

\section{Результати та дискусія}

Представимо результати, які отримано за “Опитувальником суб'єктивного соціального благополуччя” (Т.В. Данильченко). Слід зауважити, що за даними автора, отримано статистично значущі відмінності за всіма шкалами (крім шкали “Соціальна помітність") між жіночою та чоловічою вибірками, тому первинні результати оброблено окремо для чоловіків та жінок, переведено до шкали стенів. До загальної таблиці для подальшого аналізування внесено показники за стеновою шкалою (див. табл. 1).

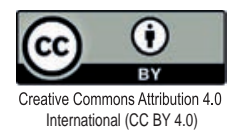


Subjective social well-being of employees with different socioeconomic statuses

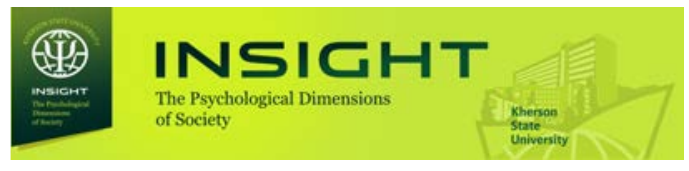

На основі порівняння даних 3 нормативними показниками за шкалами методики визначено, що за шкалою "соціальна помітність" отримано середній рівень прояву цієї характеристики (M = 5.84; SD = 1.273); приблизно однакові за кількістю частини вибірки співробітників мають високий та вище за середній рівень соціальної помітності, та, відповідно, низький та нижче за середній рівень.

За шкалою "соціальна дистантність" ми отримали вище за середні оцінки $(\mathrm{M}=6.12$; $\mathrm{SD}=1.351)$. Ми вважаємо, що наявність певної частини співробітників досліджуваної вибірки, які мають високі показники за цією шкалою, пояснюється переживанням особистістю відчуженості від соціальних відносин різних рівнів, можливо, наявністю незадовільних соціальних відносин, водночас, неможливістю змінити соціальне оточення та соціальне становище. Можна припустити, що одним із чинників, який впливає на виникнення таких переживань, $є$ загальна складна соціально-політична та економічна ситуація в країні. Т.В. Данильченко стверджує, що вираженість соціальної дистанційованості підвищує рівень соціального неблагополуччя особистості (Данильченко, 2015). Цей висновок підтверджують й наші дані про те, що за шкалою “Емоційне прийняття" отримані показники, які перевищують середньонормативні оцінки (M = 6.76; $\mathrm{SD}=1.437)$, тобто значущою для досліджуваної групи $є$ наявність соціальної підтримки та визнання від близького соціального оточення - родичів та друзів. За шкалами "Соціальне схвалення" (M = 5.29; $\mathrm{SD}=1.083$ ) та "Позитивні соціальні судження" $(\mathrm{M}=5,41 ; \mathrm{SD}=1.122)$ отримано середні оцінки у вибірці.

Проаналізуємо результати за шкалами методики “Опитувальник суб”єктивного економічного благополуччя" (В.O. Хащенко) (табл. 2).

За всіма шкалами середні показники відповідають середньонормативним значенням: “Суб”єктивна адекватність доходу запитам та потребам особистості" (M = 12,17; SD = 1.124); "Поточне благополуччя сім'ї" (M = 11,09; $\mathrm{SD}=2.018)$; “Фінансова депривованість" (M = 13,67; $\mathrm{SD}=1.842)$; "Економічний оптимізм та впевненість" (M = 14,58; $\mathrm{SD}=1.905)$; "Економічна тривожність" (M = 16,15; $\mathrm{SD}=2.017)$. Такі дані статистично є малоінформативними, these differences when averaging.

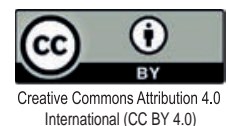


Table 2. Mean values and standard deviations on the scales of the Questionnaire of Subjective Economic Well-Being" (V.O. Khashchenko) $(\mathrm{n}=38)$

Таблиця 2. Середні значення та

середньоквадратичні відхилення за шкалами методики “Опитувальник суб’єктивного економічного благополуччя” (В.О. Хащенко) (n = 38)

\begin{tabular}{|c|c|c|}
\hline $\begin{array}{c}\text { Scale name } \\
\text { Назва шкал }\end{array}$ & M & SD \\
\hline $\begin{array}{l}\text { IIA- index of subjective income } \\
\text { adequacy to demands and needs of a } \\
\text { person } \\
\text { IAД - індекс суб'єктивної адекват- } \\
\text { ності доходу запитам та потребам } \\
\text { особистості }\end{array}$ & 12.17 & 2.124 \\
\hline $\begin{array}{l}\text { FWBI - family well-being index } \\
\text { ІБС - індекс поточного благопо- } \\
\text { луччя сім'ї }\end{array}$ & 11.09 & 2.018 \\
\hline $\begin{array}{l}\text { FDI - financial deprivation index } \\
\text { IHД - індекс фінансової } \\
\text { депривованості }\end{array}$ & 13.67 & 1.842 \\
\hline $\begin{array}{l}\text { EOI - economic optimism index } \\
\text { IEO - індекс економічного опти- } \\
\text { мізму та впевненості }\end{array}$ & 14.58 & 1.905 \\
\hline $\begin{array}{l}\text { EAI - economic anxiety index (it } \\
\text { shows the degree of financial stress) } \\
\text { IET - індекс економічної тривож- } \\
\text { ності, відображає міру виразності } \\
\text { фінансового стресу }\end{array}$ & 16.15 & 2.017 \\
\hline
\end{tabular}

Note: *a scale name in the table is in line with the pole scale with high scores; $\mathrm{M}$ - arithmetic mean; SD - mean square deviation.

Примітка: *назва шкал у таблиці відповідає полюсу шкали з високими балами; M - середнє арифметичне; SD - середнє квадратичне відхилення.

To get data on the interrelation between the parameters of subjective social well-being and economic well-being, the authors have applied Spearman's rank correlation coefficient (see table 3).

There is direct statistically significant correlation interaction between the "Social visibility" scale and indices of the Questionnaire of Economic Well-Being": IIA $\left(\mathrm{r}_{\mathrm{s}}=.318 ; \mathrm{p}<.05\right)$, FWBI $\left(\mathrm{r}_{\mathrm{s}}=.326 ; \mathrm{p}<.05\right)$, FDI $\left(\mathrm{r}_{\mathrm{s}}^{\mathrm{s}}=.417 ; \mathrm{p}<.01\right)$, IET $\left(\mathrm{r}_{\mathrm{s}} \stackrel{\mathrm{s}}{=}-.321 ; \mathrm{p}<.05\right)$. Such findings indicate that a social person, who participates in the vital activity of the group and the community, feels his/her fairly high social status and the ability to influence the social situation; at the same time, he/ she has a higher level of economic well-being. The person is satisfied with income and the principle of its distribution, life standard, highly assesses проте підтверджують гіпотезу про наявність відмінностей між підгрупами з різним соціально-економічним статусом, що при усередненні нівелює ці відмінності.

Для отримання інформації щодо взаємозв'язку між параметрами суб'єктивного соціального благополуччя та економічного благополуччя нами застосовано кореляційний аналіз за критерієм Спірмена (табл. 3).

Отримано прямий статистично значущий кореляційний зв'язок між шкалою “Соціальна помітність" та індексами опитувальника “Суб'єктивне економічне благополуччя": ІАД $\left(\mathrm{r}_{\mathrm{s}}=.318 ; \mathrm{p}<.05\right)$, IБC $\left(\mathrm{r}_{\mathrm{s}}=.326 ; \mathrm{p}<.05\right)$, IEO $\left(\mathrm{r}_{\mathrm{s}}=.417\right.$; $\mathrm{p}<.01)$, IET $\left(\mathrm{r}_{\mathrm{s}}=-.321 ; \mathrm{p}<.05\right)$. Такі результати свідчать про те, що соціально активна людина, яка бере участь у життєдіяльності групи та спільноти, відчуває свій достатньо високий соціальний статус та можливість впливати на соціальну ситуацію, водночас має більш високий рівень економічного благополуччя. Така людина задоволена доходом та справедливістю його розподілу, стандартом життя, високо оцінює фінансову безпеку та незалежність, позитивні очікування стосовно свого економічного майбутнього, відповідно, низький рівень економічної тривожності.

Встановлено кореляцію між шкалою “Соціальна дистантність” та індексом економічної тривожності $\left(\mathrm{r}_{\mathrm{s}}=.357 ; \mathrm{p}<.05\right)$, тобто людина, яка має незадовільні емоційні стосунки, неможливість змінити своє соціальне оточення, відсутність ресурсів впливу, переживає економічну тривожність стосовно матеріальних можливостей, негативне ставлення до свого фінансового становища.

Шкала "Емоційне прийняття" на статистично значущому рівні корелює з ІБС $\left(\mathrm{r}_{\mathrm{s}}=0.337\right.$; $\mathrm{p}<.05)$ та з IEO $\left(\mathrm{r}_{\mathrm{s}}=.368 ; \mathrm{p}<.05\right)$, на наш погляд, такий взаємозв'язок є закономірним та констатує, що наявність соціальної підтримки з боку близьких осіб, задоволеність стосунками зумовлює і більш позитивну оцінку свого матеріального і фінансового майбутнього.

Встановлено кореляційний зв'язок шкали суб'єктивного соціального благополуччя "Соціальне схвалення" із індексом економічного оптимізму $\left(\mathrm{r}_{\mathrm{s}}=.329 ; \mathrm{p}<.05\right)$ та індексом економічної тривожності $\left(\mathrm{r}_{\mathrm{s}}=-0.353\right.$; 
Table 3. Correlation interrelations between the scales of the Questionnaire of Subjective Social Well-Being and Subjective Economic Well-Being $(\mathrm{n}=38)$

Таблиця 3. Кореляційні взаємозв’язки шкал “Опитувальника параметрів суб’єктивного соціального благополуччя" з індексами “Суб’єктивне економічне благополуччя” (n = 38)

\begin{tabular}{|c|c|c|c|c|c|}
\hline \multirow{2}{*}{$\begin{array}{c}\text { Questionnaire of Subjective Social } \\
\text { Well-Being } \\
\text { Опитувальник параметрів } \\
\text { суб'єктивного соціального } \\
\text { благополуччя }\end{array}$} & \multicolumn{5}{|c|}{$\begin{array}{l}\text { Questionnaire of Subjective Economic Well-Being (indices) } \\
\text { Опитувальник “Суб’єктивне економічне благополуччя” } \\
\text { (індекси) }\end{array}$} \\
\hline & $\begin{array}{l}\text { IIA } \\
\text { IAД }\end{array}$ & $\begin{array}{l}\text { FWBI } \\
\text { IБC }\end{array}$ & $\begin{array}{l}\text { FDI } \\
\text { IHД }\end{array}$ & $\begin{array}{l}\text { EOI } \\
\text { IEO }\end{array}$ & $\begin{array}{l}\text { EAI } \\
\text { IET }\end{array}$ \\
\hline $\begin{array}{l}\text { Social visibility } \\
\text { Соціальна помітність }\end{array}$ & $.318^{*}$ & $.326^{*}$ & - & $.417^{* *}$ & $-.321^{*}$ \\
\hline $\begin{array}{l}\text { Social distance } \\
\text { Емоційне прийняття }\end{array}$ & - & - & - & - & $.357^{*}$ \\
\hline $\begin{array}{l}\text { Emotional acceptance } \\
\text { Соціальна дистантність }\end{array}$ & - & $.337^{*}$ & - & $.368^{*}$ & - \\
\hline $\begin{array}{l}\text { Social approval } \\
\text { Соціальне схвалення }\end{array}$ & - & - & - & $.329 *$ & $-.353^{*}$ \\
\hline $\begin{array}{l}\text { Positive social judgments } \\
\text { Позитивні соціальні судження }\end{array}$ & - & - & - & $.413^{* *}$ & - \\
\hline
\end{tabular}

Notes: ${ }^{*}-\mathrm{p} \leq .05 ;^{* *}-\mathrm{p} \leq .01$; IIA - index of subjective income adequacy to demands and needs of a person; FWBI - family well-being index; FDI - financial deprivation index; EOI - economic optimism index; EAI - economic anxiety index.

Примітка: ${ }^{*}-\mathrm{p} \leq .05$; $^{*}-\mathrm{p} \leq .01$; ІАД - індекс суб'єктивної адекватності доходу запитам та потребам особистості; ІБС - індекс поточного благополуччя сім’ї; ІНД - індекс фінансової депривованості; IEO - індекс економічного оптимізму; IET - індекс економічної тривожності.

his/her financial security and independence, positive expectations of economic future, and thus, has a low level of economic anxiety.

It has been established the correlation between "Social distance" and the index of economic anxiety $\left(r_{s}=.357 ; p<.05\right)$, i.e., a person who has unsatisfactory emotional relations, inability to change his social environment, a lack of influence resources experiences economic anxiety about financial opportunities, a negative attitude to his/ her financial situation.

The scale "Emotional acceptance" correlates with FWBI $\left(\mathrm{r}_{\mathrm{s}}=.337\right.$; $\left.\mathrm{p}<.05\right)$ and EOI $\left(\mathrm{r}_{\mathrm{s}}=.368\right.$; $\mathrm{p}<.05$ ) at the statistically significant level; in the authors' opinion, such a correlation is natural and confirms that social support from loved ones, satisfaction with relationships leads to a more positive assessment of the material and financial future.

The study has fixed the correlation between the scale "Social approval" of subjective social wellbeing" and the economic optimism index $\left(r_{\mathrm{s}}=.329\right.$; $\mathrm{p}<.05)$ as well the economic anxiety index $\left(r_{s}=-.353 ; p<.05\right)$; it is substantiated by the fact that a positive outcome of social comparison, when personal achievements demonstrate the effectiveness of social functioning, is a reason for economic optimism towards own future and thus, reduces economic anxiety. The economic optimism index is interrelated with the scale $\mathrm{p}<$ 0.05), пояснюємо тим, що позитивний результат соціального порівняння, коли власні досягнення показують ефективність соціального функціонування $€$ підставою для економічного оптимізму стосовно свого майбутнього і, відповідно, знижує економічну тривожність. Також "Індекс економічного оптимізму” взаємопов'язаний із шкалою “Позитивні економічні судження" $\left(\mathrm{r}_{\mathrm{s}}=.413 ; \mathrm{p}<.01\right)$, тобто позитивні соціальні уявлення про інших людей (їхню довіру, доброту, чесність), які $є$ наслідком життєвого досвіду особистості, зумовлюють більш високий рівень суб'єктивного економічного благополуччя.

Для доведення статистичної різниці між двома вибірками (Група 1 - високий соціальноекономічний статус ( $\mathrm{n}=18) ;$ Група 2 - низький соціально-економічний статус (n = 21) застосовано критерій кутового перетворення Фішера (табл. 4). Для порівняння взято відсоток осіб із кожної підгрупи, які мають високий рівень прояву досліджуваної ознаки (див. табл. 4).

Встановлено статистичну різницю між досліджуваними групами (група 1 та група 2) за

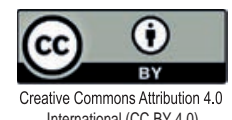


"Positive economic judgments" $(\mathrm{r}=.413$; $\mathrm{p}<.01)$, i.e., positive visions of others (their trust, kindness, honesty), which are effects of the person's life experience, lead to a higher level of subjective economic well-being.

To prove the statistical difference between the two samples (Group 1 - high socioeconomic status ( $\mathrm{n}=18$ ); Group 2 - low socioeconomic status $(\mathrm{n}=21)$ ), the authors have applied Fisher transformation (see table 4). The percentage of people from each subgroup, who have a high level of manifestation of the feature under consideration, has been used for comparison (table 4).

The statistical difference between the studied groups (group 1 and group 2) in specific parameters has been established. Group 1 (with high socioeconomic status) has higher figures compared to group 2 (with a low певними параметрами. Група 1 (з високим соціально-економічним статусом) має більш високі показники порівняно із групою 2 (з низьким соціально-економічним статусом) за такими шкалами “Опитувальника суб'єктивного соціального благополуччя" - "Соціальна помітність” ( $\left.\varphi_{\text {емп. }}=1.73 ; \mathrm{p} \leq .05\right)$, “Позитивні соціальні судження" $\left(\varphi_{\text {емп. }}=1.87 ; \mathrm{p} \leq .05\right)$, тобто об'єктивний показник соціально-економічного статусу безпосередньо пов'язаний із усвідомленням своєї впливовості, своїх ресурсів стосовно власної кар'єри, з активною життєвою позицією, здатністю вирішувати проблеми, брати відповідальність за результати та наслідки своїх дій. Такий висновок підтверджується наявністю статистично значущих відмінностей між групами за шкалою “Соціальна дистантність" $\left(\varphi_{\text {емп. }}=2.12 ; \mathrm{p} \leq .05\right)$ - показник у групі 2

Table 4. Statistical difference between the groups in the criteria of subjective social well-being and subjective economic well-being $\left(\mathrm{n}_{1}=17 ; \mathrm{n}_{2}=21\right)$

Таблиця 4. Статистична різниця між групами за показниками суб'єктивного соціального благополуччя та суб'єктивного економічного благополуччя $\left(\mathrm{n}_{1}=17 ; \mathrm{n}_{2}=21\right)$

\begin{tabular}{|c|c|c|c|c|}
\hline $\begin{array}{l}\text { Criterion name } \\
\text { Назва показника }\end{array}$ & $\begin{array}{l}\text { Group 1/ Група } 1 \\
\left.\text { (n } n_{1}=17\right), \%\end{array}$ & $\begin{array}{l}\text { Group 2/ Група } 2 \\
\quad\left(n_{2}=21\right), \%\end{array}$ & $\begin{array}{c}\text { F-test } \\
\text { Критерій } \\
\text { Фішера }\end{array}$ & $\begin{array}{l}\text { Significance } \\
\text { level } \\
\text { Рiвень } \\
\text { значущості }\end{array}$ \\
\hline $\begin{array}{l}\text { Social visibility } \\
\text { Соціальна помітність }\end{array}$ & 44.4 & 19.04 & 1.73 & $\mathrm{p} \leq .05$ \\
\hline $\begin{array}{l}\text { Social distance } \\
\text { Соціальна дистантність }\end{array}$ & 16.7 & 47.6 & 2.12 & $\mathrm{p} \leq .05$ \\
\hline $\begin{array}{l}\text { Emotional acceptance } \\
\text { Емоційне прийняття }\end{array}$ & 38.8 & 42.8 & .25 & - \\
\hline $\begin{array}{l}\text { Social approval } \\
\text { Соціальне схвалення }\end{array}$ & 22.2 & 33.3 & .77 & - \\
\hline $\begin{array}{l}\text { Positive social judgments } \\
\text { Позитивні соціальні судження }\end{array}$ & 33.3 & 9.52 & 1.87 & $\mathrm{p} \leq .05$ \\
\hline $\begin{array}{l}\text { IIA- index of subjective income } \\
\text { adequacy } \\
\text { IАД - індекс суб'єктивної адек- } \\
\text { ватності доходу }\end{array}$ & 27.7 & 19.04 & .61 & - \\
\hline $\begin{array}{l}\text { FWBI - family well-being index } \\
\text { ІБС - індекс поточного } \\
\text { благополуччя сім'ї }\end{array}$ & 16.7 & 23.8 & .55 & - \\
\hline $\begin{array}{l}\text { FDI - financial deprivation index } \\
\text { IHД - індекс фінансової } \\
\text { депривованості }\end{array}$ & 11.1 & 33.3 & 1.71 & $\mathrm{p} \leq 0.05$ \\
\hline $\begin{array}{l}\text { EOI - economic optimism index } \\
\text { IEO - індекс економічного } \\
\text { оптимізму }\end{array}$ & 38.8 & 9.52 & 2.23 & $\mathrm{p} \leq .05$ \\
\hline $\begin{array}{l}\text { EAI - economic anxiety index } \\
\text { IET - індекс економічної } \\
\text { тривожності }\end{array}$ & 22.2 & 47.6 & 1.68 & $\mathrm{p} \leq .05$ \\
\hline
\end{tabular}


Subjective social well-being of employees with different socioeconomic statuses

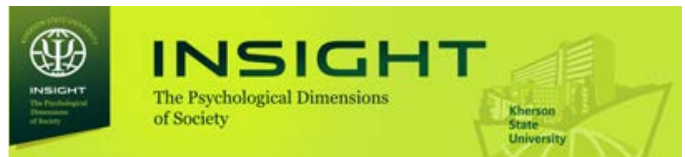

$\epsilon$ нижчим порівняно із співробітниками, які належать до групи менеджерів.

За індексами економічного благополуччя нами встановлено статистичну різницю між групами за "Індексом економічного оптимізму” ( $\left.\varphi_{\text {емп. }}=2.23 ; \mathrm{p} \leq .05\right)$, за цією шкалою показники групи 1 перевищують показники групи 2, а також за "Індексом фінансової депривованості" $\left(\varphi_{\text {емп. }}=1.71 ; \mathrm{p} \leq .05\right)$ та "Індексом економічної тривожності" ( $\left.\varphi_{\text {емп. }}=1.68 ; \mathrm{p} \leq .05\right)$, де показники групи “виконавців", тобто співробітників з більш низьким соціально-економічним статусом, є статистично нижчими.

\section{Висновки}

На основі результатів теоретичного аналізування та проведеного емпіричного дослідження ми дійшли таких висновків:

1) Встановлено статистично значущі взаємозв'язки між параметрами суб'єктивного соціального благополуччя та шкалами методики “Суб'єктивне економічне благополуччя", які відображають суб'єктивну оцінку особистістю свого соціально-економічного статусу, зокрема, прямі зв'язки між шкалами “Соціальна помітність”, “Соціальне схвалення" $(\mathrm{p}<.05)$ та індексами фінансового благополуччя, економічного оптимізму, тобто соціальна активність людини забезпечує більший рівень впевненості у своєму позитивному економічному майбутньому. Такі висновки підтверджують зворотні кореляції шкали "Соціальна дистантність" з індексом економічної тривожності.

2) 3'ясовано, що наявність соціальної підтримки близьких осіб, задоволеність особистісними стосунками зумовлюють більш позитивні очікування стосовно свого економічного майбутнього $(\mathrm{p}<.05)$.

3) Констатовано наявність відмінностей між двома групами, які розділено за соціально-економічним статусом (менеджери та "виконавці"), а саме, за шкалами “Соціальна помітність”, “Позитивні соціальні судження”, "Індекс економічного оптимізму" (у групи менеджерів показники є вищими); “Соціальна дистантність”, "Індекс фінансової депривованості", "Індекс економічної тривожності" (у групи менеджерів показники $є$ нижчими).

Враховуючи значення суб'єктивного соціального благополуччя для забезпечення оптимального функціонування персоналу в організації, відповідні знання будуть корисними counseling. 


\section{References:}

Arshava, I. F., Nosenko, D. V. (2012). Subiektyvne blahopoluchchia i yoho indyvidualno-psykholohichni ta osobystisni koreliaty [Subjective well-being and its individual psychological and personal correlates]. Visnyk Dnipropetrovskoho universytetu. Seriia: Pedahohika i psykholohiia - Bulletin of Dnipropetrovsk University. Series: Pedagogy and Psychology, 20(18), 3-9.

Chopik, W. J. (2017). Associations among relational values, support, health, and well-being across the adult lifespan. Personal Relatioships, 24(2), 408-422.

Choudhury, S. R., Barman, A. (2014). Holistic model of subjective well-being. A proposed model and exploration of context. ZENITH International Journal of Multidisciplinary Research, 4(3), 259-278.

Danylchenko, T. V. (2015). Pytalnyk "Subiektyvne sotsialne blahopoluchchia": metodolohichne obgruntuvannia i protsedura rozrobky [Questionnaire "Subjective social well-being": methodological justification and procedure development]. East European Scientific Journal, 3(4), 20-29.

Danylchenko, T. V. (2017). Psykholohichna struktura sotsialnoho blahopoluchchia ta neblahopoluchchia [Psychological structure of social well-being and unhappiness]. Ukrainskyi psykholohichnyi zhurnal - Ukrainian Psychological Journal, 2(4), 7-22.

Diener, E. (2013). The Remarkable Changes in the Science of Subjective Well-Being. Perspectives on Psychological Science, 8(6), 663- 666.

Donald, G. Gardner (2020). The importance of being resilient: Psychological well-being, job autonomy, and self-esteem of organization managers. Personality and Individual Differences, 155. https://doi.org/10.1016/j.paid.2019.109731

Fofanova, G. A., Gavrilchik, E. V. (2017). Sub'ektivnoe ekonomicheskoe blagopoluchie studentov yunosheskogo vozrasta [Subjective economic well-being of young students]. Zhurnal Belorusskogo gosudarstvennogo universiteta. Filosofiya. Psihologiya - Journal of the Belarusian State University. Philosophy. Psychology, 2, 92-97.

Haschenko, V.A. (2011). Sub'ektivnoe ekonomicheskoe blagopoluchie i ego izmerenie: postroenie oprosnika i ego validizatsiya [Subjective economic well-being and its measurement: questionnaire arrangement and its validation]. Eksperimentalnaya psihologiya Experimental psychology, 4(1), 106-127.

Husiev, I. M. (2013). Subiektyvne perezhyvannia bidnosti moloddiu: problema vymiriuvannia ta psykholohichnyi zmist [Youth's subjective experience of poverty: the issues of measurement and psychological content]. Visnyk Odeskoho natsionalnoho universytetu. Seriia: Psykholohiia - Bulletin of Odessa National University. Series: Psychology, 18(22), 185-191.

Kanibolotska, M. S. (2014). Osoblyvosti stavlennia do zdorovia molodi z vysokym ekonomichnym statusom: rezultaty doslidzhennia [Features of the attitude towards health of young people with high economic status: study results]. Naukovyi visnyk Chernivetskoho natsionalnoho universytetu imeni Yuriia FedkovychaScientific Bulletin of Yuri Fedkovych National University of Chernivtsi, 678, 67-74. для керівництва організації та психологічного консультування.

\section{Список використаних джерел}

Аршава I. Ф., Носенко Д. В. Суб'єктивне благополуччя i його індивідуальнопсихологічні та особистісні кореляти. Вісник Дніпропетровського університету. Серія: Педагогіка і психологія. 2012. Т. 20, вип. 18. C. 3-9. Режим доступу: http://nbuv.gov.ua/UJRN/ vdupp_2012_20_18_3

Chopik W. J. Associations among relational values, support, health, and well-being across the adult lifespan. Personal Relatioships. 2017. Vol. 24. Issue 2. P. 408-422. https://doi.org/10.1111/pere.12187

Choudhury S. R., Barman A. Holistic model of subjective well-being. A proposed model and exploration of context. ZENITH International Journal of Multidisciplinary Research. 2014. Vol. 4. Issue 3. P. 259-278.

Данильченко Т. В. Питальник “Суб”єктивне соціальне благополуччя": методологічне обгрунтування і процедура розробки. East European Scientific Journal. 2015. №3(4). C. 20-29.

Данильченко Т.В. Психологічна структура соціального благополуччя та неблагополуччя. Український психологічний журнал. 2017. № 2(4). C. 7-22.

Diener E. The Remarkable Changes in the Science of Subjective Well-Being. Perspectives on Psychological Science. 2013. Vol. 8. Issue 6. P. 663-666. https://doi.org/10.1177/1745691613507583

Donald G.Gardner The importance of being resilient: Psychological well-being, job autonomy, and self-esteem of organization managers. Personality and Individual Differences. Volume 155, 1 March 2020, 109731 https://doi.org/10.1016/j. paid.2019.109731

Фофанова Г. А., Гаврильчик Е. В. Субъективное экономическое благополучие студентов юношеского возраста. Журнал Белорусского государственного университета. Философия. Психология. 2017. №2. С.92-97.

Хащенко В. А. Субъективное экономическое благополучие и его измерение: построение опросника и его валидизация. Экспериментальная психология. 2011. Т. 4. № 1. C. 106-127.

Гусєв I. М. Суб'єктивне переживання бідності молоддю: проблема вимірювання та психологічний зміст. Вісник Одеського національного університету. Серія: Психологія. 2013. Т. 18. Вип. 22, част.1. С. 185- 191.

Каніболоцька М. С. Особливості ставлення до здоров'я молоді 3 високим економічним статусом: результати дослідження. Науковий вісник Чернівецького національного університету імені Юрія Федьковича: Зб. наук. праць Чернівецького нац. ун-ту ім. Юрія 
Subjective social well-being of employees with different socioeconomic statuses

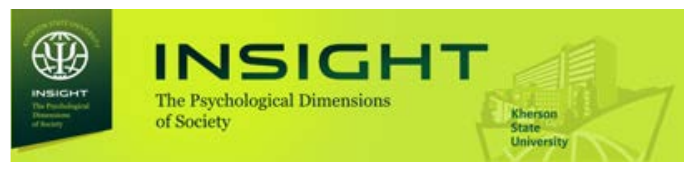

Федьковича. Чернівці. 2014. Вип. 678. С. 67-74.

Keyes C. L., Westerhof G. J. Chronological and subjective age differences in flourishing mental health and major depressive episode. Aging Mental Health. 2012. Vol. 16. P. 67-74. https://doi.org/10.1080/13607863.2011.596811

Коробка Л.М. Соціально-психологічні особливості здоров'я громадян із різним матеріальним становищем. Наукові студіі із соціальної та політичної психології : збірник статей / НАПН України, Ін-т соціальної та політичної психології; [ред.. рада: М. М. Слюсаревський (голова), В. Г. Кремінь]. К.: Міленіум, 2012. Вип. 30 (33). С.114-125.

Круглов К.О., Блинова О.Є. Значення соціального капіталу для психологічного благополуччя співробітників. Інсайт: психологічні виміри суспільства:наук.журнал,2019.Вип.1.C.72-78.DOI: https://doi.org/10.32999/2663-970X/2019-1-11

Круглов К. О., Блискун О. О. Особливості суб'єктивного соціального благополуччя молодих співробітників в організації. Науковий вісник Херсонського державного університету. Серія: Психологічні науки. 2020. Вип. 4. С.100107. DOI https://doi.org/10.32999/ksu23123206/2020-4-14

La Placa V., McNaught A., Knight A. Discourse on wellbeing in research and practice. International Journal of Wellbeing. 2013. Vol. 3. Issue 1. P. 116-125. DOI: $10.5502 /$ ijw.v3i1.7

Min Gwan Shin, Young-Ki Kim, Se-Yeoung Kim, Dong Mug Kang Relationship Between Job Training and Subjective Well-being In Accordance With Work Creativity, Task Variety, and Occupation. Safety and Health at Work. Volume 11, Issue 4, December 2020. P. 466-478. https://doi.org/10.1016/j.shaw.2020.08.006

МуздыбаевК. Переживаниебедностикаксоциальной неудачи: атрибуция ответственности, стратегии совладания и индикаторы депривации. Социологический журнал. 2001. № 1. C. 5-32. [Електронний ресурс]. Режим доступу : http://www.nir.ru/sj/sj/sj1-01muz.html

Овчарова Л.Н. Теоретико-методологические вопросы определения и измерения бедности. Spero. 2012. №16. С. 15-38.

Родіна Н.В. Соціально-економічний статус і копінг у контексті безпеки особистості. Вісник Одеського національного університету. Серія: Психологічні науки. 2013. Т. 18. Вип.24. С. 215-222.

Шамионов Р.М. Субъективное благополучие личности как субъекта социального бытия. Известия Саратовского университета. Серия: Философия. Психология. Педагогика. 2014. Т. 14, вып. 1. С. 80-86. well-being of the individual as a subject of social life]. Izvestiya Saratovskogo universiteta. Seriya: Filosofiya. Psihologiya. Pedagogika - Bulletin of the Saratov University. Series: Philosophy. Psychology. Pedagogy, 14(1), 80-86. 